\title{
Experimental Estimation of the Effect of Rainfall Interception on Soil Respiration in a Broad-leaved Deciduous Forest in Western Japan
}

\author{
Koji Tamai* \\ Forestry \& Forest Products Research Institute, Matsunosato, Tsukuba, Ibaraki 305-8687, Japan \\ (Received June 4, 2009; Revised October 27, 2009; Accepted November 20, 2009) \\ 일본 서부 낙엽활엽수림의 차단 강수가 토양호흡에 미치는 영향 평가 \\ 타마이 코지* \\ 일본 독립행정법인 삼림총합연구소 \\ (2009년 6월 4일 접수; 2009년 10월 27일 수정; 2009년 11월 20일 수락)
}

\begin{abstract}
To estimate the effect of rainfall on soil respiration, soil $\mathrm{CO}_{2}$ efflux was measured with a manipulation of rainfall interception at a broad-leaved deciduous forest in western Japan from 20 February to 19 November 2001. The diurnal patterns of soil respiration observed at the intercepted subplot $\left(F_{c}\right)$ were quite similar to those of soil temperature at $0.2 \mathrm{~m}$ depth with a maximum around midnight and a minimum from noon to early afternoon. Such diurnal patterns have not been observed in the previous studies at the same study site under natural conditions (which manifested no clear diurnal variations). Furthermore, the magnitudes of $F_{c}$ showed substantial differences (e.g., $\sim 50 \%$ reduction under waterlimited conditions) compared to those of the potential soil respiration under natural conditions $\left(F_{c a l}\right)$. These findings demonstrate that rainfall events not only affected the magnitude of soil $\mathrm{CO}_{2}$ efflux but also modified the vertical structure of soil temperature, thereby altering diurnal patterns of soil respiration.
\end{abstract}

Key words : Soil respiration, Rainfall, Soil temperature, Soil moisture, Deciduous forest

\section{INTRODUCTION}

Soil respiration is an important component in $\mathrm{CO}_{2}$ exchange between forests and the atmosphere to determine whether a forest is a carbon sink or source (e.g., Kominami et al., 2008). Better understanding of soil respiration is, therefore, critical to reduce uncertainties in diagnosis and predictability for future climate changes and mitigation of their impacts. Several factors affect soil respiration and it has been reported that soil temperature and moisture are the key variables controlling soil respiration (e.g., Davidson et al., 2000). In particular, alteration of rainfall amounts results in changes in surface runoff and soil water content and then affects soil respiration. Although there have been numerous studies to ascertain the effects of soil temperature and soil moisture content on soil respiration, a few attempts have been made to examine the role of rainfall by an artificial interception. In this research note, such an attempt was made by artificially intercepting rainfalls for 9 months in a broad-leaved deciduous forest in western Japan and the consequent soil respiration observed at the intercepted site is presented.

\section{SITE DESCRIPTION}

The study site was in the Yamashiro Experimental Forest in southern Kyoto Prefecture, Japan (Fig. 1(a);

\footnotetext{
* Corresponding Author: Koji Tamai (a123@affrc.go.jp)
} 

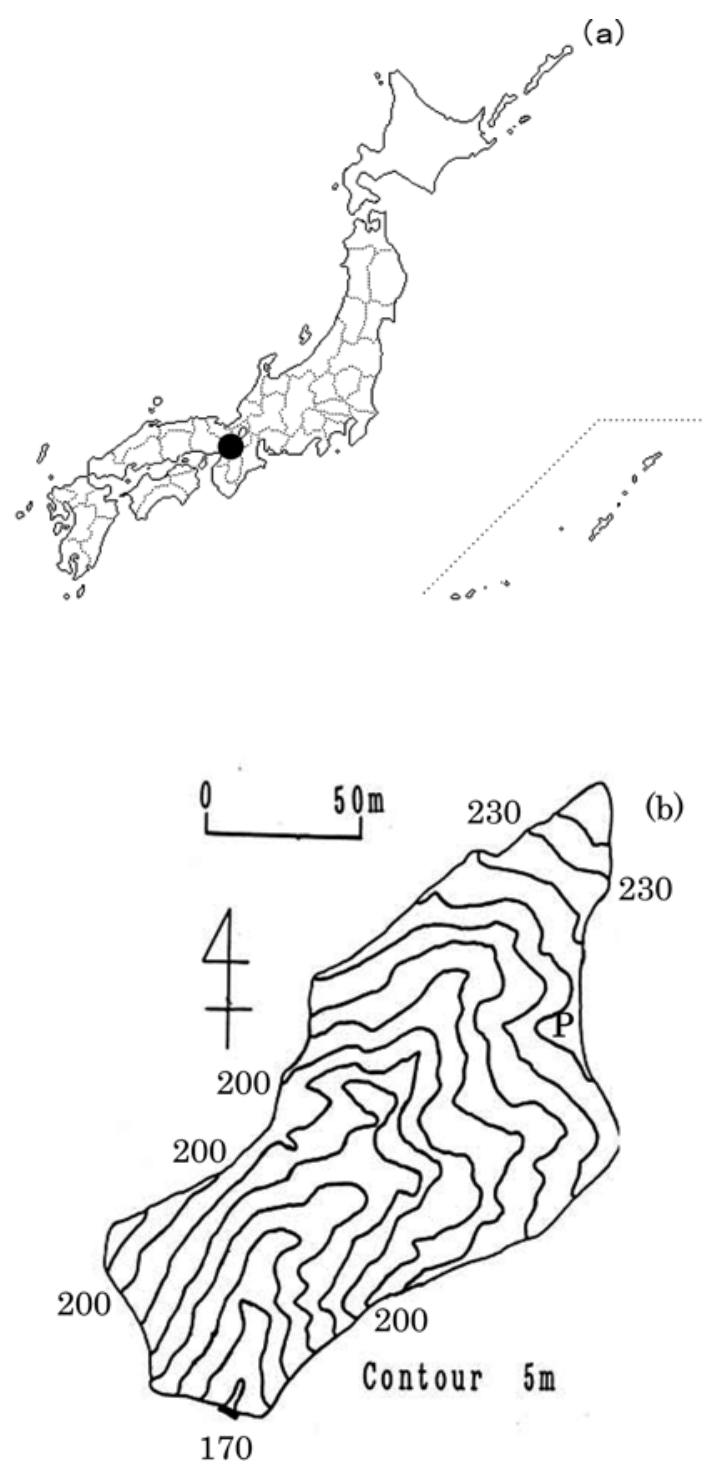

Fig. 1. Location and topography of the Yamashiro Experimental Forest and the study plots. (a) Location of the Yamashiro Experimental Forest (Black circle: Yamashiro Experimental Forest) and (b) Site topography with the experimental observation plot $(\mathrm{P})$ (the numbers indicate altitude in $\mathrm{m}$ ).

$34^{\circ} 47^{\prime} \mathrm{N}, 135^{\circ} 50^{\prime} \mathrm{E}$ ). Most of the trees planted in the late 19th century have died and the current deciduous forest site is dominated mainly by tree species such as Prunus verecunda, Ilex pedunculosa, and Quercus glanca. The average litter fall from 1999 to 2002 was $5.16 \mathrm{t} \mathrm{ha}^{-1}$ year $^{-1}$, with a mean air temperature of 15.5 ${ }^{\circ} \mathrm{C}$, warmth index of $125.6{ }^{\circ} \mathrm{C}$ month, and annual precipitation of $1,449 \mathrm{~mm}$ (Goto et al., 2003). Soil is regosol of sandy loam or loamy sand and contains fine granitic gravel. The average soil depth is $0.47 \mathrm{~m}$ and the dry weight of litter in the basin was about $400 \mathrm{~g} \mathrm{~m}^{-2}$. More detailed information about the study site can be found at Tamai et al. (2008).

\section{METHODS AND MATERIALS}

The experimental observation plot was prepared on a ridge (Fig. 1(b)) and consisted of two subplots which were adjacent to each other. In the "intercepted subplot", rainfall was artificially intercepted with turfs $(0.7$ $\mathrm{m} \times 0.7 \mathrm{~m}$ ) settled at $0.3 \mathrm{~m}$ above the ground and the forest soil remained dry throughout the measurement period. In the "standard subplot," natural conditions were maintained. Soil respiration in the intercepted subplot $\left(F_{c}: \mathrm{mg} \mathrm{CO}_{2} \mathrm{~m}^{-2} \mathrm{~s}^{-1}\right)$ was observed with an automated closed chamber with a built-in infrared gas analyzer (GMD-20, Vaisala, Finland). This chamber is a kind of static closed chamber and produced the $\mathrm{CO}_{2}$ fluxes comparable to those of the dynamic closed chamber with a LI-800 (Li-COR, USA) over a wide range (Nobuhiro et al., 2003). In this study, one measurement cycle consisted of a 25 -min closed period and a 5-min open period. The soil temperature and volumetric water content were also observed at 0.05 and $0.20 \mathrm{~m}$ depths in the standard subplot with temperature probes (Model 107, Campbell scientific, USA) and time domain reflectometers (CS615, Campbell scientific, USA), respectively from 20 February to 19 November 2001.

To confirm the rain effect, water equivalent to 2.5 $\mathrm{mm}$ of precipitation was applied as the artificial rainfall event on the soil and the surrounding areas during the 08:55-09:00 am on 6 July 2001.

To estimate soil respiration from the soil temperature and moisture in the standard subplot at the site $\left(F_{c a l}\right)$, we used the following equation from Tamai et al. (2008):

$$
F_{c a l}=0.0566 \operatorname{EXP}\left(0.0717 T_{5}\right)\left(\frac{\theta_{5}}{0.1089+\theta_{5}}\right)
$$

where $F_{c a l}$ is the calculated soil respiration $\left(\mathrm{mg} \mathrm{CO}_{2} \mathrm{~m}^{-2} \mathrm{~s}^{-1}\right)$ which can be regarded as the potential soil respiration under natural conditions (i.e., without an artificial interception of rainfall). $T_{5}$ and $\theta_{5}$ are the soil temperature $\left({ }^{\circ} \mathrm{C}\right)$ and volumetric soil water content $\left(\mathrm{m}^{3} \mathrm{~m}^{-3}\right)$ observed at $0.05 \mathrm{~m}$ depth in the standard site, respectively.

To quantify statistical measure of relationship between 
soil temperature and soil respiration, root mean square error (RMSE) was calculated with standardized $T_{5}, T_{20}$, and $F_{c}(\mathrm{ST})$ :

$$
\begin{aligned}
& \operatorname{ST}\left(T_{i}\right)=\left[T_{i}-\operatorname{MiN}\left(T_{i}\right)\right] /\left[\operatorname{MAX}\left(T_{i}\right)-\operatorname{MiN}\left(T_{i}\right)\right] \\
& \operatorname{ST}\left(F_{c}\right)=\left[F_{c}-\operatorname{MIN}\left(F_{c}\right)\right] /\left[\operatorname{MAX}\left(F_{c}\right)-\operatorname{MiN}\left(F_{c}\right)\right]
\end{aligned}
$$

where $\operatorname{ST}\left(T_{i}\right)$ and $\operatorname{ST}\left(F_{c}\right)$ are the standardized values of soil temperature and $F_{c}$ (where the subscript $i$ indicates the measurement depth), and MAX and MIN are the daily maximum and minimum values of $T_{5}, T_{20}$, or $F_{c}$. RMSE between the standardized soil temperature and the standardized soil respiration is given to:

$$
\operatorname{RMSE}\left(T_{i}\right)=\left[\left(\operatorname{S~}\left\{\operatorname{ST}\left(F_{c}\right)-\operatorname{ST}\left(T_{i}\right)\right\}^{2}\right) / N\right]^{0.5}
$$

where $N$ is the number of data.

\section{RESULTS AND DISCUSSION}

Fig. 2 shows the diurnal variation of soil respiration $\left(F_{c}\right)$ observed at the intercepted subplot from a selected period (i.e., 4 to 12 June 2001). The diurnal patterns of $F_{c}$ were obvious with a maximum around midnight and a minimum from noon to early afternoon, which were very similar to those of soil temperature at $0.2 \mathrm{~m}$ depth. According to the prior study at the same site, such a clear diurnal variation of soil respiration during the
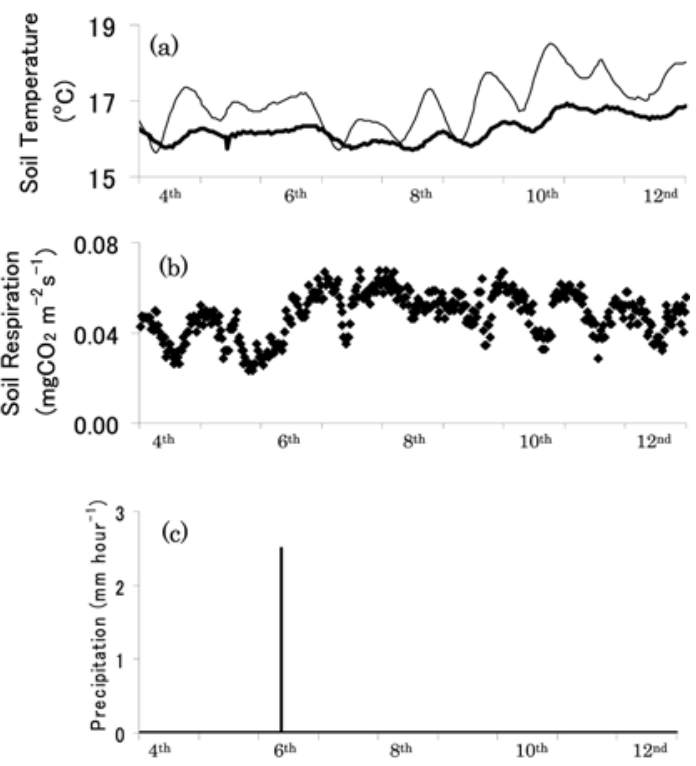

Fig. 2. Time series of the (a) observed soil temperature at 0.05 and $0.2 \mathrm{~m}$ depths, with thin and thick lines, respectively, (b) soil respiration $\left(F_{c}\right)$, and (c) precipitation at the intercepted subplot from 4 to 12 June 2001.
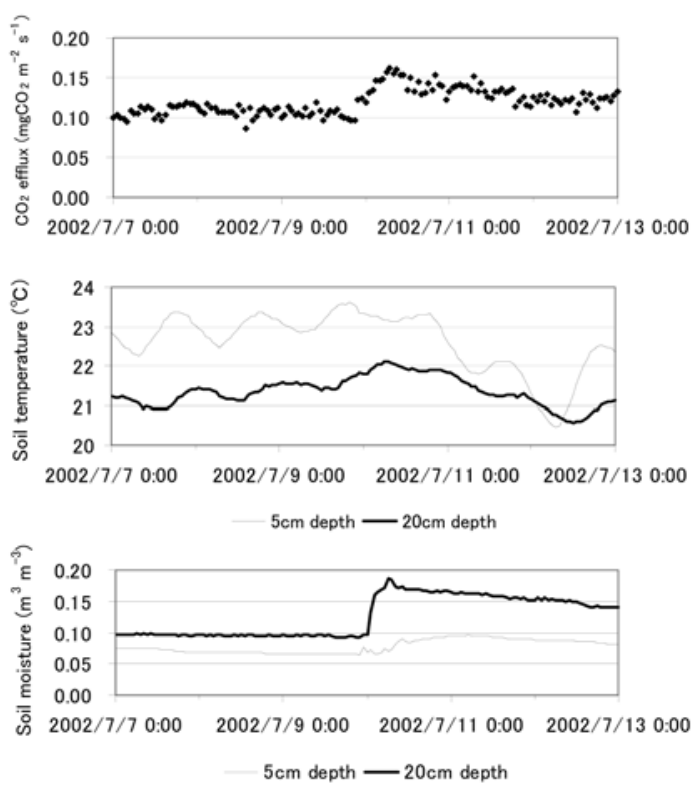

Fig. 3. Diurnal patterns of soil respiration (upper), soil temperature (middle) and soil moisture under the natural condition (bottom) (Tamai et al., 2005).

rainy periods has not been reported in the standard subplot under natural conditions (Fig. 3; Tamai et al., 2005). It is speculated that drier soil in the intercepted subplot made an impact on this diurnal variation through modification of the vertical profile of soil temperature variation. Except for a few days after the artificial rainfall application on $6 \mathrm{July}, F_{c}$ showed consistent diurnal variations with the maximum $\left(\sim 0.05 \mathrm{mg} \mathrm{s}^{-1} \mathrm{~m}^{-2}\right)$ at midnight and a minimum around noon. The soil temperature at $0.05 \mathrm{~m}\left(T_{5}\right)$ showed the minimum in mid morning and the maximum in the evening whereas the minimum and maximum soil temperatures at 0.20 $\mathrm{m}\left(T_{20}\right)$ lagged behind. Consequently, the daily variations of $F_{c}$ better correlated with those of $T_{20}$ than $T_{5}$, which was also confirmed from the results of RMSE $\left(T_{20}\right)$. The magnitudes of RMSE $\left(T_{20}\right)$ were usually smaller than those of RMSE $\left(T_{5}\right)$ (Fig. 4), indicating that the diurnal variations in $F_{c}$ were more closely related to soil temperature in a deeper layer than in the surface soil layer. Deep-soil biological processes such as root respiration governed the observed variations in $F_{c}$ at the site. When soil was dry, only a small amount of $\mathrm{CO}_{2}$ was produced by litter and organic matter decomposition in the soil.

Fig. 5 shows seasonal variations in the daily averaged $F_{c}$ and $F_{c a l}$. The differences between $F_{c}$ and $F_{c a l}$ were 


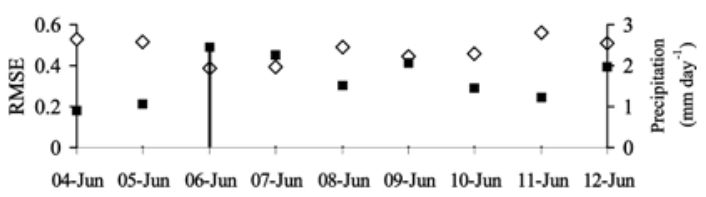

Fig. 4. RMSE between the standardized daily fluctuation of soil temperature and soil respiration and precipitation (right axis). (4-12 June 2001) White diamonds: $\operatorname{RMSE}\left(T_{5}\right)$, Black squares: $\operatorname{RMSE}\left(T_{20}\right)$, Bars: Precipitation.

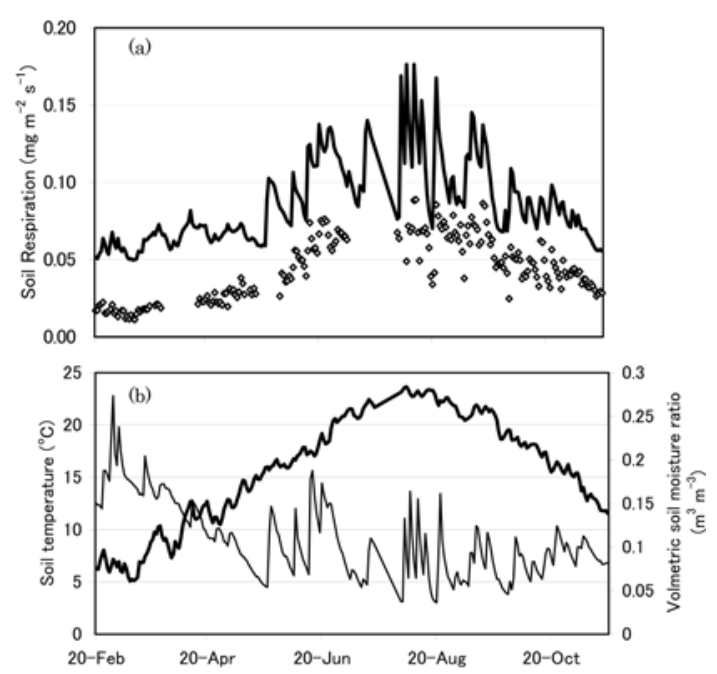

Fig. 5. Seasonal fluctuation in daily averaged values of soil respiration, soil temperature, and volumetric soil moisture at $0.05 \mathrm{~m}$ depth (20 February-19 November 2001). Solid line: Calculated potential soil respiration $\left(F_{c}\right)$; White diamonds: Observed soil respiration $\left(F_{c a l}\right)$. Thick line: Soil temperature at $5 \mathrm{~cm}$ depth $\left(T_{5}\right)$, Thin line: Volumetric soil moisture ratio $\left(q_{5}\right)$.

relatively small in August and September when soil in the standard subplot was also dry. During the rainy periods, soil moisture remained ample in the intercepted subplot and $F_{c}$ was more sensitive to $T_{5}$ compared to $F_{c a l}$.

\section{CONCLUDING REMARKS}

The soil respiration was observed in the deciduous forest floor in western Japan, where the rainfalls were intercepted for 9 months. In contrast to the soil respiration under the natural conditions, the clear diurnal patterns were observed with a maximum around midnight and a minimum between noon and early afternoon. Such patterns are synchronized to those of the soil temperature at $0.2 \mathrm{~m}$ depth, which may be partly attributed to the fact that the surface soil was too dry to be a source of a significant amount of $\mathrm{CO}_{2}$. The magnitude of soil respiration at the site with rainfall interception was also suppressed by up to $50 \%$, compared to that under the natural conditions. In summary, rainfalls siginificantly affected not only the magnitude but also the diurnal pattern of soil respiration at the study site.

\section{적 요}

강우가 토양 호흡에 미치는 영향을 평가하기 위해, 일본 서부에 위치한 활엽수림에서 2001년 2월 20일부 터 11월 19일까지 강우를 차단한 상태에서 토양 $\mathrm{CO}_{2}$ 플럭스를 측정하였다. 강우가 차단된 관측지의 토양 호 흡 $\left(F_{c}\right)$ 의 일변화는 $0.2 \mathrm{~m}$ 깊이의 토양 온도의 일변화와 매우 비슷하였으며, 자정에 최고값을 보이고 정오에서 이른 오후 사이에 최저값을 나타내었다. 이러한 뚜렷한 일변화 패턴은 같은 관측지에서 강우가 차단되지 않은 상태에서 관측된 선행연구의 결과(뚜렷한 일변화의 부 재)와 대조되었다. 또한, 자연상태의 가능토양호흡 (potential soil respiration, $F_{c a l}$ )의 크기와 비교할 때, 강 우가 차단된 관측지의 토양호흡은 매우 큰 차이(예를 들 면, 토양수분이이 부족할 때 약 $50 \%$ 감소)를 보였다. 이 연구결과는 강우가 토양 $\mathrm{CO}_{2}$ 플럭스의 크기뿐만이 아니라 토양온도의 연직 프로파일을 바꿈으로써 토양호 흡의 일변화 양상에도 영향을 미침을 보여준다.

\section{ACKNOWLEDGEMENTS}

This study was supported by the Global Environment Research Account for National Institutes Long-term Monitoring of Carbon Flux and Promotion of Data Network in Asian Terrestrial Ecosystems and Research Fund (Evaluation, Adaptation and Mitigation of Global Warming in Agriculture, Forestry and Fisheries: Research and Development) by Ministry of Agriculture, Forestry and Fisheries of Japan. I also thank the anonymous reviewers for their valuable comments.

\section{REFERENCES}

Davidson, E. A., K. Savage, L. V. Verchot, and R. Navarro, 2002: Minimizing artifacts and biases in chamber-based measurements of soil respiration. Agricultural and Forest Meteorology, 113, 21-37.

Goto, Y., Y. Kominami, T. Miyama, K. Tamai, and Y. Kanazawa, 2003: Aboveground biomass and net primary production of a broad-leaved secondary forest in the southern part of Kyoto Prefecture, central Japan. 
Bulletin of Forestry and Forest Products Research Institute, 2, 115-147. (in Japanese with English abstract).

Jia, S., T. Akiyama, W. Mo, M. Inatomi, and H. Koizumi, 2003: Temporal and spatial variability of soil respiration in a cool temperature broad-leaved forest. 1. Measurement of spatial variance and factor analysis. Japanese Journal for Ecology, 53, 13-22. (in Japanese with English abstract).

Koizumi, H., M. Kontturi, S. Mariko, T. Nakadai, and Y. Bekku, 1999. Soil respiration in three soil types in agricultural ecosystems in Finland. Acta Agriculturae Scandinavica, Section B, Soil and Plant Science, 49, 65-74.

Kominami Y., M. Jomura, M. Dannoura, Y. Goto, K. Tamai, T. Miyama, Y. Kanazawa, S. Kaneko, M. Okumura, N. Misawa, S. Hamada, T. Sasaki, H. Kimura, and Y. Ohtani, 2008: Biometric and eddy-covariance-based estimates of carbon balance for a warm-temperate mixed forest in Japan. Agricultural and Forest Meteorology, 148, 723-737.

Kosugi, Y., T. Mitani, M. Itoh, S. Noguchi, M. Tani, N. Matso, S. Takanashi, S. Ohkubo, and A. R. Nik, 2007: Spatial and temporal variation in soil respiration in a
Southeast Asian tropical rainforest. Agricultural and Forest Meteorology, 147, 16-34.

Liang N. T. Nakadai, T. Hirano, L. Qu, T. Koike, Y. Fujinuma, and G. Inoue, 2004: In situ comparison of four approaches to estimating soil $\mathrm{CO}_{2}$ efflux in a northern larch(Larix kaempferi Sarg.) forest. Agricultural and Forest Meteorology, 123, 97-117.

Nobuhiro, T., K. Tamai, Y. Kominami, T. Miyama, Y. Goto, and Y. Kanazawa, 2003: Development of IRGA enclosed-chamber system for soil $\mathrm{CO}_{2}$ efflux measurement and its application to a spatial variation measurement. Journal of Forest Research, 8, 297-301.

Tamai, K., Y. Kominami, T. Miyama, and Y. Goto, 2005: Temporal fluctuations in the $\mathrm{CO}_{2}$ efflux on a forest floorthe case of an extremely immature forest soil. Journal of Agricultural Meteorology, 60, 773-776.

Tamai, K., Y. Kominami, T. Miyama, Y. Goto, and Y. Ohtani, 2008: Topographical effects on soil respiration in a deciduous forest -The case of weathered granite region in Southern Kyoto Prefecture. Journal of Agricultural Meteorology, 64, 215-222. 